\title{
Experience of social workers in assurance of quality service for older adults in care institutions (Lithuanian context)
}

\author{
Alina Petrauskiene $^{1}$, Irena Zemaitaityte ${ }^{1}$, and Migle Maniusyte ${ }^{2}$ \\ ${ }^{1}$ Mykolas Romeris University, Vilnius, Lithuania \\ ${ }^{2}$ Center of Gerontology and Rehabilitation, Vilnius, Lithuania
}

\begin{abstract}
The aim of the article is to outline the characteristics of the work experience (feelings, efforts and interactions) of the social workers employed in social care institutions for older people in the attempt to provide quality services in practice and the perspectives of this practice. Qualitative research data collection method was used. The answers to the research question were collected by a semi-structured interview. Data analysis carried out by the inductive theme analysis method revealed that the participants of the survey feel the load of responsibility, ambiguity of a complex function and challenges of quality services in relation to the implementation of the service standards; disappointment and hesitations related to the organization of work and professional status. The strengths of the social workers lie in their commitment to the interaction with the service receivers, involvement in the service quality valuation processes in the institution, and in identifying the challenges.
\end{abstract}

\section{Introduction}

The ageing process of Lithuanian society is gaining speed, and social services for older people are becoming a substantial part of social support. The growing number of social support users - older people -requires more financial and human resources. The shrinking of self-sufficiency of individuals, the need for stationary care is also growing [1]. Though institutional long-term social care is becoming less of a target service in comparison to home provided services and care popularity, however, the individual who moves to a care institution, as a rule, stays in it for the rest of their life, therefore, the quality of care in this sector is of particular importance so that positive goals of ageing and ensuring human rights would be attained. Social workers have an established position of the key providers of social services for older adults in care institutions and they are stakeholders in the issues related to the quality of services. In 2013 Lithuania experienced the start of the licensing of the social care institutions by application of certain quality measure schemes for improvement of the social services and effectiveness of social work, enhancing transparency and accountability of the work of social care institutions [2]. Growing dominance of market economy, the cost-effectiveness of services and investment are causing changes to social work patterns. Social workers today are faced with the necessity to mind not only the required services for the client, but also foresee the social outcomes and results of the provided services [3]. Researchers stress the tendency for the social services to be oriented towards preservation of human dignity and self-sufficiency rather than responding to the key (vital) needs of individuals [4]. 
Quality assurance of social services is approached by researchers as a challenging and complex process, that calls for quality valuation criteria and models [1, 5-7]. Scientists find an argumentative foundation for Lithuanian empowering model of social services in its correspondence to the dominant social welfare ideologies and its emphasis on European Union Social Care criteria of social care quality that rest on user centred service management, empowering organization, respect of human dignity, recipients' right for making decisions and civil rights, on accessibility, openness and continuity of the services [4].

On practical level social service quality assurance requires permanent reflecting of the experience and discussion of the application of quality criteria in practice by the social workers. A meaningful condition for the assurance of the quality of social services is created through the identification of the expectations and the input of service providers $[5,8,9]$.

This provides background for the emergence of the following research question: What does the assurance of the quality of social services for older people mean for social workers?

\section{Perspectives of social service quality valuation}

Lithuania takes an active part in European processes of the implementation of social policies, under the conditions that quality valuation processes of services in European Union states are promoted, balance between service providers and receivers is highlighted, and the service providers' effect and a privileged position is restricted, and the receivers' participation and decision making are supported [4:10].

Social service quality assessment may be implemented through application of different perspectives. The European Commission in 2010 emphasized the systemic (organizational) tier in relation to the implementation of the service quality context [11]. This approach takes into account the situation and the conditions which are indispensable for the provision of services, the organizational characteristics of the implementation, legal acts, standards, modes of their control, organizational resources and the like are reviewed. One of the principles applicable to the quality assessment, is the principle of effectiveness; to seek effectiveness, however, in the sphere of social services is difficult since this aspect evades measurement and description. Effectiveness finds its expression in the comparison of all social services provided in the service system and of state budget expenditure. Satisfaction of a client's and the community's needs as well as ability to implement and fulfil service quality standards are assessed [12]. Another important principle is the social dialogue and cooperation when the provision of social services rests on the interests of all stakeholders, interinstitutional cooperation, positive interaction and self-support are developed. It is critical for the improvement of the totality of service providing environment and it is destructive when the cooperation is over-formalized through bureaucratic regulations [11]. For the assessment of the employees, the principle of competence assessment is applied. It embraces knowledge, skills, capacities and conditions for continuous competence development and perspectives. System quality for the receiver rests on the principles of universality (the complex support to the combination of social services with other systems and provisions, such as health care, employability), social justice (the capacity to pay for the services should have no effect upon the availability of the services); appropriateness (services provided should correspond to the receiver's needs and expectations to the maximum), accessibility (services are located close to the individual's residence), security (the receiver experiences no threat, risks and hesitations are minimal, confidentiality is observed) principles. To assess system tier identification of quality criteria and standardization of procedures is required. Certain features of a service provision that will be held universally mandatory should be created. In the attempt to establish the supervision of the quality of social services, their control and assessment, legal acts 
regulating these deeds should be passed, a network of institutions whose capacity would embrace this should be built. Licensing social service institutions started in Lithuania in 2013, and it embraces mostly objective quality measurement criteria [13]. On the basis of such criteria as, for example, infrastructure (construction) conditions suitable for the service needs, qualifications of the personnel, availability of appropriate filing, correspondence to the norms of social service development. These criteria rest on objective, quantitative data, which helps to measure certain aspects of quality.

On the level of service providers, social service quality can be measured by evaluating the characteristics of service providers, ways and methods of service provision, etc. Evaluation of service providers should rest on the principles of communication, which means that the service provider is capable of communicating with the receiver in a manner acceptable for the receiver, can listen to the receiver's expectations, anticipates and realizes the receiver's wishes and expectations. This principle can be paired with the user oriented principle. Implementation of the principle for the service provider most often poses the problem of the client who is incapable of voicing the requirements and expectations or sees the situation inadequately. The principle of reliability is key in providing social services, since clients in this service sector are highly vulnerable they value clarity, keeping promises, identification of time and other circumstances which allow them to trust in the service providers. The principle of reacting is in line with the reliability principle since building trust relationship the personnel is ready to extend assistance for the client. The principle of the user analysis is a continuous, systemic attempt to learn about the service receivers, assess their requirements, mind their expectations and provide service in correspondence with all. A service provider, acting on the holistic principle, seeks to construct multisided conditions for the assurance of the client's self-sufficiency. Personnel's attention is understood as an attempt to help the client, taking interest in the client, attentiveness. Responsibility and accountability for the service receiver and for the society translates as a permanent, periodic dissemination of information, achieving financial and non-financial results, their publication in openly accessible media. Compliance with the principles of partnership and cooperation are measured according to the service provider's cooperation with the service receiver and with the organizations who act in the receiver's representation, institutions of financial support, politicians and other subjects in identification of the client's needs, in planning, revising, developing, controlling and assessing service provisions [11].

The key area of assessing quality on the level of the service receiver is fulfilment of expectations. In assessing this area, the tangibility of the service must be identified first, i.e. the existence of all elements which prove that the service is really being provided. Implementation of the principle of participation means that issues of social service provision are decided with the service receiver on a par as well as with other stakeholders, directly or indirectly involved in the service provision.

Meeting the needs principle is one of the most important principles for the service receiver, the client appears on the list of the social service receivers only under the condition that certain unsatisfied needs emerge which cannot be satisfied by the client themselves. It has been mentioned before that the subjective satisfaction of the client is equally important as the objective criteria and for this reason it should be marked as an important goal. In this situation in the area of social service provision we encounter difficulties which spring from the fact that occasionally it is difficult to assess the client's, particularly of an older individual's, understanding of the quality of the service, since this is usually outside all measurable questionnaires. Another potential problem area is a possible difference between subjective and objective quality. Situations may occur when, while objective conditions for the service provision decline, subjective client's satisfaction grows [14]. When the social service quality 
is seen through the lenses of the service receiver, it is recommended that the receiver takes part in different measures for service assessment provided by the service provider or the system since this is the only way to reveal the subjective quality criterion from the perspective of the client. Neither service providers nor receivers may have identical understanding of quality therefore in drawing the standards it is important to identify expectations of the majority of service providers. This is the only way to have useful application of quality standards [15].

\section{Methods of research}

To reveal the distinctive experience of social workers in their efforts to provide quality social service for older clients a qualitative method of semi-structured interviewing was selected. Interview questions were formulated so that it would facilitate obtaining the answer to the research question. Data analysis method was inductive theme analysis [16]. Theme analysis steps were the following: revision of the collected data and its transcription; generating initial codes; identification of preliminary themes; thorough review of themes, definition and tagging the themes, analyzing themes in detail and organizing in-depth discussion.

Research participants: There participated 7 informants employed in different institutional social care organizations. The following selection characteristics were applied:

- Social workers employed in the stationary social care institutions for older people with no shorter than 3 years of employability history in that institution;

- Social workers with the university degree in social work;

- Social workers exposed to direct contact with the service receivers - residents of the care homes, older people;

- Social workers, participating in the interior quality assessment processes of the institution they work at.

Research ethics: Research participants were introduced to the research theme, aim, the organization of the interviews, and interview questions to give an opportunity to contemplate and to prepare for the process of the data collection. It was declared that the data collection and their analysis will be carried out by the principle of confidentiality. The participants of the research were given the opportunity to read the text of transcribed interviews and the final research results, to pass remarks and commentaries regarding the data reliability.

Research limitations: Though social service quality for older people is relevant to social workers' practice, the selection of research participants was complicated and limited to 7 participants. Social workers were not inclined to reflect upon their experience related to service quality assurance assessment in their institutions.

\section{Results}

The analysis of the answers produced by the research participants to the open question "What does it mean for social workers to assure quality of social services for older people in the care homes?" led to the identification of the following themes: social services quality assurance - experiencing responsibility load and uncertainty, frustrations about the imposed additional functions.

Experiencing responsibility load and uncertainty. The results of the study revealed that the research participants in their daily practice take upon themselves a huge load of responsibility in the attempt to provide quality services for their clients, they forget personal needs for the sake of the client's satisfaction with the service: “... there is a lot 
of responsibility I think I take it myself ... I forget myself and act so that the services were better for the person". "I have a lot of responsibility in this care institution, perhaps the most. I am solely responsible for quality, to make an individual satisfied, is all on my shoulders."

The participants of the research consider themselves as responsible professionals, feeling and reacting to the clients' needs, they notice in their daily practice that they are the first who the clients turn to and it is important for them to respond to the client's needs at any part of the day or night, since they feel mostly responsible for everything in relation to the clients of their institution, they prioritize the client's interests: “... we are the most sensitive in the institution ... Whatever happens, we are the first to be addressed, we are sought for, though it is obvious that things are outside our care. Clients call me on weekends, sometimes in the evenings. I have to deal with everything ....".

The research participants feel responsible for the totality of the provided services, it is difficult to define, they feel they are versatile "guarantors" of complex service provision, who can be approached and who listen to the diverse situations and problems of the clients: “... clients address me for psychological, for medical, for all social, cultural, spiritual and even mechanical, routine issues."

The research participants recognize the problem of the limitation of responsibility and acceptance of unspecified assignments when they compare work of other professionals working in the same institution, since, in the words of the research participants, other specialists are aware and indicate the limits of their responsibilities. The research participants feel the load of responsibility when they take upon themselves to straighten up the unfinished jobs of other workers of the institution; to smooth down negative issues, since they think this comes within their responsibility: "Other specialists, they complete their work and they are no longer here (they leave). Other specialists know how to say that they have no time, that something is outside their responsibility etc. I have to finish, to bend all the corners, to smooth down what was not good, what others could not resolve."

The research participants connect the assuming of the responsibility to the personal and professional qualities, they think that responsibility is seen through subjective understanding, experience, and existing formalized job description is read and interpreted by the workers differently: "... what is written in the job description is not the ultimate mark, since everyone understands responsibility individually, through internal feelings, through personal experience, through human characteristics, personal understanding."

The research participants experience hesitations in undertaking a large responsibility load, they compare and test the limits of responsibility of other specialists to their own, they feel the lack of support and understanding of other specialists and feel inequality and injustice: "Sometimes we have doubts ourselves - if what we do is for us to decide to do or not? For your knowledge we sometimes review our job description, and we find out that there is nothing close to the work or function, but we carry it out and out and out —all”; "... the role is not clear. Other specialists do not know who you are, why and what you should be doing. Then everything gets confused and then you do not know it yourself ..., the role is very complex, it is difficult to define".

The research data show that in practice of social workers there appear situations of unidentified function, which are difficult to assess on the basis of the formal job description. In such situations the research participants experience confusion, difficulty for the uncertain role they play.

Complexity of quality standards and demands of work. Interview data shows that long-term care institution social workers see the quality of social work as a body of regulations, rules, orders, which they are to put to practice: "Quality is regulations, which one has to put to life in order to provide services in general."; "Quality is what we have to match 
to in accord with the rules, regulations, documents, orders, work functions ..."; "Generally standards describe and indicate how and what activities should be carried out."; "Quality is what is stated in objective, measured points, it is clear to all, for example some social service, the order of its provision, remuneration and the like ..."; "Quality should be regulated by the law very clearly, stated in points, so that there were no deviations, ambiguities and the like".

The participants of the research associate the quality of social work with the standards and norms of activities, job description that formally indicates assessment criteria. The informants admit that the service provision quality needs to be regulated and measurable so that no ambiguities nor deviations nor interpretations occur. In other instances the research data showed that the research participants do not know how the work standards should be implemented in practice with regard to the appreciation of individual needs of a client. Implementation of standards requires discussion and common understanding among professionals and the clients: “... those standards in social work can never be fully grasped ..."; "Right, then the question is what is a standard. One considers it to be standard that a social worker makes a visit once per week, others may think that visits should be made several times per day. So there must be clarification of what and how many.”; ". . perhaps there is a place for unspoken standards. And ( $\mathrm{mmm})$ what is not officially recorded then it depends on an individually created vision, for example a worker's or a client's vision ..."; "... those standards, those documents are sometimes difficult to fathom ... "; "It is very undefined, very unclear, very abstract. One may interpret or else not understand (standards), one can apply or not apply them."

The interview data leads to the insight that implementation of quality standards for the social workers employed in the long-term social care institutions in practice poses problems: the content of the standards and documents is abstract and unclear, understood differently and differently interpreted.

Experiencing frustration about imposed additional functions. The participants of the survey experience frustration of depreciation when the representatives of other professions (doctors, nurses) and their administrative superiors ignore the functions of social work and seek to appoint to social workers casual assignments that require no competence of social workers: "When I started my work, senior doctor asked me: "So what will your function here be?"; "... in our institution it is difficult to grasp what is the difference between social work and nursing."

"It happens that the administration thinks of such jobs that cannot be appointed to anyone, then we are given this, since they think that we have most of spare time and our work is less urgent in comparison to others.',

The participants of the research feel frustrated about depreciation of their professional role, when administration and other specialists try to educate them, do not appreciate the complexity of their work, time resources and the scope of tasks: “... all are telling us of what we should do ... it seems, that our work is elementary ...”.

The participants of the research feel frustration and hopelessness since they are incapable of resisting the pressure of administration and other specialists when they have to substitute other workers for the period of their vacation or temporary leave: “... when some specialists are not at work, ... a social worker is appointed as a substitute ...” The participants confess that on such occasions they feel bad not only for the reason that the importance of their own work is not duely appreciated but also because they cannot commit to their professional engagement as they should: "I happen to have substituted a secretary for a few days while she was on a sick leave. I felt very bad since I was thinking about my direct tasks which I could not carry out at the moment." The participants admit that because of the staff shortage they carry out the tasks which should be given to other workers and they feel frustrated about 
this: “. . we have shortage of lower level workers, lower staff, and we carry out their function. ... one gets disappointed with the studies, our degree and the remuneration is for doing other work, which does not require any particular competence ...”.

\section{Discussion}

The core of the social work lies in improvement of quality of life of socially vulnerable individuals [9]. The aim of the social service provision is seen as the assistance of the service providers to the receivers in dealing with the social problems in accord with the principles of social service provision and implementation [17]. It is possible to identify that the field of action of the social workers, the participants of the research, in order to gain the aims of the social service for the older people is very broad, it is cumbersome to define it and according to the participants of the research, they are responsible for everything that is connected to the quality enhancement of the client's life, needs and solving social problems. The participants of the research relate the quality of social service to clients' satisfaction with the service received and they take upon themselves a huge load of responsibility focusing on the meeting of the clients' needs, also taking charge of the works unfinished by other specialists or other indiscriminate tasks. The participants of the research feel that clients and representatives of other professions can hardly grasp function and scope of work of a social worker in a care institution, though it is observed [18] that older clients do not discriminate functions of either social workers or other workers in the care institution. The participants of the research feel it their duty to maintain the contact with the clients and other specialists, they appear in situations in their practice when it is complicated to be guided by straightforward job descriptions and standards of function, though these are indicated as necessary for the quality assurance. In their opinion quality of service should be measurable and attainable and implemented with regard to service provision standards and norms. The problem is that for the research participants the difficulty lies in understanding and application of standards in uncertain situations with individual client's fully. The researchers [18, 19] indicate that service quality assessment should rest on universally acceptable and understandable standards, i.e. assessable standards of care quality at the institutions should be measurable, steeped in practice, appropriate for internal institutional assessment and suitable for external control.

Research data indicates that the participants of the research hold the contact with the client as key in service quality assurance, they acknowledge the importance of a direct, reliable, timely contact, emphatic attention to the client's needs and stability. Social workers for the sake of the service quality and mediating expectations of the clients resort to their own internal strengths, professional competence, and life experience. Clients, to quote the words of the research participants, turn to the social workers first, they trust service quality when they meet an authoritative, humane, able to predict their expectations and structure the situation clearly social worker. Qualitative and empowering service should be provided when they are appreciated and improved through the received feedback from the users and the founders of a particular service (a state, an NGO or a private enterprise) [4].

Research data lists situations when social workers feel frustration because of the function imposed onto them by the administration of the organization, they live through periods of doubt, disappointment in carrying out those functions, but they continue in their performance since they hold that their priority is extending assistance to the client, humanistic goals, on other occasions they take them as duty, something that cannot be avoided. Social workers experience frustration in carrying out indeterminate activities that are imposed on them. Practice of social work is complex, it does not give itself to easy definitions, social workers can encounter periods of hesitation about their values, convictions, emotions, 
identification of self and the world around (ontological indeterminacy); hesitations about the appropriateness, application and critical revision (epistemiologic indeterminacy) of the accumulated knowledge; hesitations of the work organization, service provision and the function of the organization (procedural indeterminacy). It is considered that indeterminacy will not disappear from social work practice in the future, therefore, social workers will have to "tame" it by adopting a critical view, which would help to identify professional, clients' and organizational needs and support resources [3]. When addressing the inefficiency of institutional resources, it is obvious that such institutions cannot offer nor provide complete quality service for their clients [4]. It is accepted [20] that for the development of social work (which is inseparable from dealing with issues of the social service quality enhancement) the organizational environment that promotes professionalism (critical thinking) is indispensable, in the reverse situation efforts and energy wasted on the internal tensions and overcoming of stressful situations of social workers, imitation of "good" social work or coming to terms with the existing situation (in this case) in the institutions of social care.

\section{Afterword}

Social work quality assurance for older people in the care homes for social workers translates into maintenance of a long-term, sensitive, reliable and professional contact with the clients, meeting client's needs, taking the load of responsibility, experiencing indeterminateness of the complex function, hesitations about the organization of work, relations with administration of care institution and professional status. The participants of the research experience difficulties in enhancing quality for older people services related to the ambiguities of the application of standards, when it is difficult to interpret them, implement and explain their benefits for the service receivers.

Social services quality enhancement may be related to the development of the social work when in the care institution a feedback information is gathered and cooperation with the service receivers is not interrupted, when the competence improvement of the employees is associated with their involvement into quality assessment processes, through the participation of the workers their professional interests are revealed and subjective criteria of service quality is identified.

\section{References}

[1] A. Bitinas, A. Guogis, 1. Migun, V. Važgytè. Social Work, 9(1), 18-26 (2010).

[2] Socialinis pranešimas (2013-2014). http://www.socmin.lt/lt/socialinispranesimas.html

[3] R. Rimkus. Tiltai, 1, 99-113 (2015).

[4] D. Dvarionas, R. Motiečienè, J. Ruškus, N. Mažeikienè, R. Naujanienė. Filosofija. Sociologija, 25(2), 89-97 (2014).

[5] V. Indrašienė V, A. Katkonienè. Socialinis darbas, 10(2), 262-278 (2011).

[6] A. Kazlauskienè, I. Ostrauskienè. Socialiniai tyrimai 2(19), 20-26 (2010).

[7] L. Žalimienè, Socialinès globos pagyvenusiems asmenims kokybè ir jos vertinimas. Vilnius: Efrata, 2005.

[8] M. Maniušytė. Socialinio darbo kokybė ir jos vertinimas institucinės socialinès globos istaigose senyvo amžiaus asmenims. Magistro darbas. Mykolo Romerio universitetas (2013).

[9] B. Blom, S. Moren. Nordic Journal of Social Research, 2, 71-87 (2012). Available online at: https://boap.uib.no/index.php/njsr/article/viewFile/205/ 312. 
[10] H. Nies, R. V. Veen, R. Rodrigues et al. Quality Management and Quality Assurance in Long - Term Care // European Overview Paper (2010). Available online at: http://www.euro.centre.org/data/1278594919_52528.pdf

[11] European Commission. Common Quality Framework for Social Services of General Interest (2010) Available online at: http://cms.horus . be/files/99931/ Newsletter/3-CEN-WSA-51-Common-Quality-Framework-SSGI .pdf

[12] A. Guogis, D. Gudelis. Viešoji politika ir administravimas, 12(1), 77-85 (2005).

[13] Dèl Socialinès globos istaigụ licencijavimo taisykliụ patvirtinimo. Lietuvos Respublikos vyriausybės nutarimas (2013) Available online at: https : //www . e-tar . lt/portal/legalAct .html?documentId=TAR . AA8A6CEDFB4F

[14] European Centre for Social Welfare Policy and Research. Measuring progress: indicators for care homes (2010) Available online at: http://www.euro. centre.org/data/progress/PROGRESS_ENGLISH.pdf

[15] A. Kaziliūnas. Kokybės analizè, planavimas ir auditas. Vilnius: Mykolo Romerio universiteto leidybos centras (2006).

[16] V. Braun, V. Clarke. Thematic Analysis (2012) Available online at: http://www. academia.edu/3789893/Braun_Clarke_2012_APA_TA_Chapter.

[17] L. Žalimienè. Ekonomika ir vadyba: aktualijos ir perspektyvos. 1(6) 183-189 (2006).

[18] F. Kerr, J. Gordon, Ch. MacDonald, K. Stalker. Scottish Executive Social Research (2005). Available online at: http://scotland.gov.uk/Resource/Doc/47121/ 0020809.pdf

[19] K. Leichsenring. Health systems and long-term care for older people in Europe (2011) Available online at: http://www.integratedcare.org/Portals/0/uploads/ congresses/Leichsenring $\% 20$ Wagner $\% 20$ Health $\% 20$ systems $\% 20$ and $\% 201$ ong $\%$ 20 term $\% 20$ care.pdf

[20] B. Švedaitè-Sakalauskè, L. Gvaldaitè, J. Buzaitytė-Kašalynienè. Socialinè teorija, empirija, politika ir praktika, 9, 21-36 (2014). 